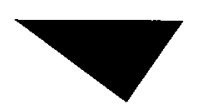

\title{
O MST na TV: sublimação do político, moralismo e crônica cotidiana do nosso "estado de natureza"1
}

\author{
Alessandra Aldé $^{*}$ e Fernando Lattman-Weltman ${ }^{* *}$ \\ IUPERJ/Fundação Getúlio Vargas
}

Resumo: $O$ artigo procura analisar os enquadramentos predominanter na cobertura dada às açôes do MST pelo Jornal Nacional (Globo) e TJ Brasil (SBT) en agosto de 1997, um nês de coberfura ordinciria.

Siruamos o MST como um dos assuntos políticos de maior visibilidade nos telejornais de maior audiência do país, e conchúmos que ambos apostanam no potencial sensacional do tema. asando recorrentemente enquadramentos que reforçavam a violência e tensão inerentes ao conflito. Enquanto, porém. o Tl reforgava os elementos de perigo, iminencia de combate, confronto e polarização, mum enquadramento predominantemente dramático, e ao julgar o MST assumia um fon crítico e moralista apenas em relação ao uso que este fazia da violência polínica. o IN assumia, além desse tipo de juizo especificamente moral, jurídico e político, um enquadramento racionalista em relação ao movimen10. negando a ele capacidade técnica e, portanto, racionalidade econômica.
Abstract: This article intends to analyze the main frames given to the actions of the Landless Workers Movement (MST) by the two most watched national evening new's programs, Jornal Nacional (G/obo) e Tu Brasil (SBT), during the ordinary coverage of Alugust, 1997. We locate the Movenent as one of the most visible political issues on both programs, and conclude that both emphasized the sensationalism of the issue. using plenty of frames that stressed the violence and tension inherent to conflict. While TJ reinforced mainly the elenents of danger, imminence of combar. confrontation and polarization, in a dramatic frame, and in its judgement of MST it assumed a critical and moralistic posture only about the Movement's use of political violence. Jornal Nacional asstmed, in addition to this specifically moral. juridical and political frame, a rationalist frame, which denied MST technical capacity, and therefore economical rationality.

\footnotetext{
* Pesquisador do Centro de Pesquisa c Documentação de História Contemporânea do Brasil, Cpdoc, da Fundaçāo Getúlio Vargas e co-autor de A Imprensa Faze Desfaz. um Presidente, Editora Nova Frontcira. Rio de Janciro, 1994

** Jornalista, mestre e doutoranda em Ciência Política no luperj. pesquisadora do Doxa (Laboratório de Pesquisa em Comunicação Política e Opinião Pública), do Iuperj, professora auxiliar do departamento de Sociologia e Ciência Política da PUCRJ.
} 
Com este trabalho iniciamos uma série de análises de conteúdo no sentido de investigar a maneira pela qual a mídia constrói narrativas básicas para a definição coletiva dos conteúdos da cidadania em nosso país e acerca das funções e desempenhos de suas instituições.

Com a intenção de identificar os enquadramentos existentes e predominantes na cobertura dos conflitos políticos, bem como o tipo de narrativa utilizado nas matérias, analisamos aqui a cobertura telejornalística feita a partir das ações do Movimento dos Trabalhadores Sem-Terra (MST), num total de 19 matérias, sendo 12 do Jornal Nacional (JN), da Rede Globo de Televisão, e 7 do TJ Brasil 90 (TJ), do Sistema Brasileiro de Televisão (SBT), veiculadas entre 28 de julho e 30 de agosto de 1997.

O MST caracteriza-se como um dos poucos movimentos - senão o único - a desafiar francamente o status quo brasileiro contemporâneo, propondo-se a romper os limites usualmente aceitos da legalidade no sentido de forçar a realização de seu objetivos, em especial a redistribuição da propriedade fundiária no Brasil, através da reforma agrária.

Desse modo, a análise dos padrões de leitura - vale dizer, de inteligibilidade - dos discursos televisivos sobre o comportamento do MST e de suas implicações para a ordem democrática, pode nos ajudar a compreender as principais motivações e constrangimentos impostos à mídia - e a seu diferentes veículos - no processo cotidiano de (re)produção das narrativas coletivas acerca dos sentido e valores básicos de nossa sociedade.

Enquadramento do conflito: drama e moral na luta pela terra

A cobertura midiática dos movimentos de oposição e dos conflitos políticos encontra no conceito de enquadramento uma chave de análise eficaz.

Para Erving Goffman, um dos primeiros a sistematizar um conceito genérico para enquadramentos, estes são "definições da situação construídas de acordo com princípios de organização que governam os eventos - ao menos os eventos sociais - e nosso envolvimento subjetivo com eles"'. Estas estruturas cognitivas, que organizam o pensamento, são compostas de crenças, atitudes, valores e preferências, bem como de regras a respeito de como ligar diferentes idéias. São esquemas, que "...dirigem a atenção para a informação relevante, guiam sua interpretação e avaliação, fornecem inferências quando a informação é falha ou ambígua, e facilitam sua retenção"2. Trata-se, portanto, de construções culturais que se realizam na narrativa, na articulação.

Um dos campos privilegiados de produção de enquadramentos, 
uma vez aceita a realidade de um mundo em que a política e a cultura atuam crescentemente na esfera da mídia, é o dos meios de comunicação de massa: "Enquadramentos de mídia são padrões persistentes de cognição, interpretação e apresentação. de seleção, ênfase e exclusão, através dos quais os manipuladores de símbolos organizam rotineiramente o discurso, seja verbal ou visual" 3 .

Nesse sentido, como o mito, o estereótipo e o arquétipo, as notícias podem atuar na difusão de valores e explicações estruturais a respeito do mundo público, naturalizando um mundo relativamente distante da experiência direta dos indivíduos. "Os fatos, nomes e detalhes modificam-se quase diariamente, mas a estrutura na qual se enquadram - o sistema simbólico - é mais duradoura" ". Desse modo, a mídia nunca opera no vazio; as narrativas que produz são resultado de sua interação com os eventos e seus protagonistas - sua matéria-prima -, além de conterem uma série de expectativas com relação à audiência, cuja fidelidade é vital para os meios de comunicação de massa e que convive com outros enquadramentos, oriundos de outras fontes ${ }^{6}$. No estabelecimento dessa sintonia com a audiência, a televisão muitas vezes reproduz e reforça elementos dominantes de cada cultura, num círculo de que é impossível determinar o ponto de partida.

Por outro lado, ao se inserirem na economia política concreta os meios de comunicação de modo algum se limitam a reproduzir os padrões de enquadramento vigentes: como atores interessados eles interferem diretamente nessa reprodução, mesmo que sua própria intervenção seja limitada estruturalmente - tanto cognitiva quanto ideologicamente - por suas condições de produção e pelas variações históricas, sociais e culturais que se impõe sobre as diferentes formas de consumo e recepção dessa mesma produção.

No estudo ora apresentado, nos limitamos a uma faceta de apenas uma destas relações: centramos a análise nos enquadramentos usados pelos principais telejornais do país para narrar os eventos envolvendo o MST, os fazendeiros e o governo (os três protagonistas do drama em questão), e oferecidos a uma audiência numericamente - e, logo, politicamente -- importante.

Ambas as coberturas faziam uso de um enquadramento de conflito em relação ao Movimento dos Sem-Terra, embora com diferenças fundamentais. De um lado, o TJ reforçava os elementos de violência, perigo, iminência de combate, confronto e hostilidade entre os adversários: eram enfatizados os elementos sensacionais do conflito, caracterizando o que chamaremos de um enquadramento dramático, com predomínio de um enfoque extremamente polarizado dos ad- 
versários. O JN, por sua vez, sem deixar de lado esses elementos predominantes em ambos os noticiários - assumia um papel também moralista em relação ao movimento, arvorando-se contudo em juiz e dando elementos para apelos à lei e à ordem: lamentava, assim, a invasão de terras produtivas, a irracionalidade e irresponsabilidade dos sem-terra, o mau uso da terra distribuída e advogava a viabilidade de outras formas, pacíficas, para solução do problema da terra. Trata-se de um enquadramento moralista, já identificado em estudos sobre a cobertura jornalística dada no Brasil aos escândalos políticos que marcaram os anos recentes ${ }^{7}$.

92 Além destes dois enquadramentos principais, vários outros são sugeridos ao longo das notícias, muitas vezes usando-as dialeticamente, fazendo o contraponto entre a atuação dos sem-terra e do governo através das imagens e da narração dos fatos, sem que seja preciso opinar explicitamente, através de comentários dos âncoras ou especialistas dos telejornais.

Antes de proceder com a descrição e análise das notícias, procuraremos situar a cobertura feita ao MST pelos telejornais de agosto de 1997 no interior do cenário informativo mais amplo dos canais abertos de televisão.

\section{O espaço informativo: alguns números sobre os telejornais de agosto}

Além de analisar de modo geral a cobertura dada pelos dois telejornais de âmbito nacional com a maior audiência do país, a intenção deste estudo é comparar, ainda que superficialmente, as matérias do $\mathrm{JN}$ às do $\mathrm{TJ}$, procurando ressaltar as semelhanças e diferenças no enquadramento dado ao conflito. Antes de mais nada, convém situar o leitor em relação ao lugar ocupado pelas matérias sobre o MST no universo informativo oferecido por cada emissora aos telespectadores.

O JN segue indo ao ar de segunda a sábado, das $20 \mathrm{~h}$ até aproximadamente 20:45, sendo precedido pela novela das sete (à época, "Zazá") e seguido pela das oito ("A Indomada"). O TJ, também exibido de segunda a sábado, vinha sofrendo mudanças nos meses anteriores: após a saída de Bóris Casoy, em junho, sofreu queda de audiência de um ponto, passando de 8 para $7 \%$. Em agosto, o noticiário passou para as 18:30, acarretando nova queda de audiência, de 7 para $6 \%$, baixando, em outubro, para $4 \%$. Ainda assim tratava-se de uma audiência significativa em termos nacionais: cada ponto percentual representava cerca de 410 mil espectadores em 9 regiões metropolitanas, segundo pesquisa do IBOPE. Em dezembro daquele 
ano, o telejornal foi retirado da programação, sem previsão para voltar. No horário precedente, a programação do SBT exibia o jornalístico-policial "AquiAgora", também extinto, e, depois, o programa infantil de desenhos animados "Disney World".

Entre 28 de julho e 2 de setembro de 1997, em pouco mais de cinco semanas, foram veiculadas 32 edições de cada telejornal, num total de 940 matérias. Esta amostra foi limitada ao acervo que tínhamos em mãos, mas justifica-se como ilustrando um período fora dos eventos extraordinários que, em termos de cobertura jornalística, marcaram o ano de 1997 para o MST. Com efeito, já haviam se passado mais de três meses desde a Marcha a Brasília, em abril; o julgamento de José Rainha, embora presente, não estava em primeiro plano; finalmente, ainda não estava em pauta a polêmica gerada pela decisão da sem-terra Débora Rodrigues de posar nua na revista Playboy. Podemos inferir que tratou-se, assim, de um mês de cobertura normal, que nos permite uma aproximação ao modo como o jornalismo televisivo situa, rotineiramente, o MST.

\begin{tabular}{|lccc|}
\hline \multicolumn{4}{|c|}{ Quadro 1. Principais temas } \\
Tema & IN & TI & Total \\
\hline Internacional & 50 & 76 & 126 \\
\hline Esportes & 53 & 45 & 98 \\
\hline Variedades/curiosidades & 43 & 29 & 72 \\
\hline Economia & 30 & 30 & 60 \\
\hline Violência & 17 & 22 & 39 \\
\hline Acidentes/desastres & 17 & 19 & 36 \\
\hline Crime/sistema penal & 18 & 12 & 30 \\
\hline Legislação & 14 & 16 & 30 \\
\hline Governo Federal & 13 & 16 & 29 \\
\hline Polícia & 10 & 16 & 26 \\
\hline Saúde & 13 & 10 & 23 \\
\hline Ecologia/meio-ambiente & 19 & 3 & 22 \\
\hline Lazer/cultura & 4 & 12 & 16 \\
\hline Corrupção & 10 & 4 & 14 \\
\hline
\end{tabular}

O MST aparecia no JN com oito matérias, empatando com temas como "Ciência e tecnologia", "Segurança" e "Sociedade Civil", e superando temas como "Defesa do consumidor", "Habitação/favelas" e "Judiciário", cada um com sete matérias. No TJ, com seis matérias, além do MST, havia temas como o "Congresso (Câmara/Senado)" (tema que só ganhou três matérias no JN), "Partidos políticos" e "Políticos".

Comparada aos demais temas políticos, portanto, a visibilidade do 
MST nos noticiários ficava evidente, especialmente se considerarmos a abrangência da maioria dos temas, bem mais genéricos. Os temas internacionais, na maioria das vezes, apareciam em curtos flashes com menos de um minuto sobre conflitos, tragédias - como a morte de Lady Diana, ocorrida no fim do período -, política ou curiosidades.

A maior matéria do período, do JN, durou 9'06": foi a primeira da série promovida pela própria emissora sobre a venda ilegal de armas, com a participação da polícia. Interessante notar que, entre as dez maiores notícias veiculadas no período pelo $\mathrm{JN}$, as únicas com cinco minutos ou mais, seis pertenciam a esta série de reportagens, incluindo sua repercussão junto às autoridades e ao público. Três trataram da morte da princesa Diana, e a última deu início a mais uma série de reportagens promovida pela emissora a respeito da ineficiência dos portos brasileiros, com o nome geral de "Custo Brasil".

No SBT, o leque de temas foi mais variado. A maior matéria, com 6'49", cobria a morte da princesa. Em termos de tempo, a maioria das matérias, nos dois jornais, situava-se na faixa entre 1 e dois minutos. As 14 matérias veiculadas sobre a questão agrária e o Movimento dos Sem-Terra não fugiam portanto ao padrão.

No TJ, embora o número de matérias fosse menor, o tema ganhava maior destaque: as notícias eram, em média, maiores que as do $\mathrm{JN}$, e o assunto chegou duas vezes a ganhar a primeira matéria do jornal, destaque ampliado pelo fato deste telejornal não apresentar chamadas antes do primeiro bloco.

A seguir apresentamos uma análise sucinta do conteúdo dessas matérias, com ênfase nas principais diferenças comparativas entre os dois telejornais. Para ilustrar os diferentes enquadramentos, incluímos a descrição das matérias mais significativas.

\section{Tensão e ameaça: o conflito moralizado e o conflito sensacional}

Enquanto a análise quantitativa dos telejornais de agosto nos situa em relação à visibilidade do MST, uma análise mais detalhada das 14 matérias que, neste período, trataram da reforma agrária e do Movimento dos Sem-Terra, nos permitirá identificar os enquadramentos usados. As cinco matérias restantes, embora classificadas sob outro tema primário, foram incluídas por também tocarem a questão, e por influírem no enquadramento proposto para o MST.

As próprias vinhetas utilizadas como fundo quando o apresentador do telejornal iniciava cada notícia já nos deram pistas sobre o foco de cada cobertura. A do JN mostrava uma pegada fresca na terra avermelhada, sobrepondo-se a três fios de arame farpado: neste caso, o recurso do MST à invasão era enquadrado negativamente pela alusão à violação da proprie- 
dade, e tomava-se o principal elemento significativo da vinheta. Os semterra, antes de mais nada, são invasores de propriedade.

No TJ, víamos, sobre um fundo vermelho composto com bandeira do MST, a silhueta escura de um camponês, identificado pelo chapéu, que levava ao ombro uma espingarda. A cor vermelha e a presença da arma indicavam violência e conflito, que davam a tônica do enquadramento dramático proposto pelo telejornal. A presença da bandeira, além disso, ilustrava a dimensão política do Movimento que, como veremos, tem alguma importância no enquadramento proposto. Embora em muitos momentos o TJ, assim como o JN, desqualificasse a atuação política do MST frente às autoridades constituídas, sua cobertura parecia abrir espaço bem maior para o Movimento enquanto organização política, construindo assim um personagem de maior impacto dentro de uma narrativa que enfatizava a polarização e dramaticidade do conflito.

\begin{tabular}{|c|c|}
\hline \multicolumn{2}{|l|}{ Quadro 2. Matérias sobre o MST } \\
\hline Data $n^{\circ}$ Título/resumo & Témpo \\
\hline I) Jornal Nacional & \\
\hline $05 / 087$ Sem-terra matam gado $\mathrm{cm}$ lazenda produtiva invadida & $1: 02$ \\
\hline $05 / 08$ \& Agricultores recebem incentivo municipal para voltar ao campo & 1.53 \\
\hline 13/08 15 Pontal: ameaça de invasões leva donos a reforçar segurança & $0: 32$ \\
\hline 13/08 16 Governo federal cria nova linha de crédito rural & $0: 15$ \\
\hline 13/08 17 No MT, polícia impede saque de armazćm pelos sem-terTa & $0: 15$ \\
\hline 16/08 12 Pontal: Iensão c ameaça de invasão pelo MST & $0: 48$ \\
\hline $19 / 0820$ Rainha acusa governo c Incra de prejudicar a reforma agrária & $0: 36$ \\
\hline 20/08 5 MST invade lazenda e donos da lerra se armam & 2:(07 \\
\hline 26/08 17 Sem-tema invadem fazenda sem laudo de improdutividade & $0: 24$ \\
\hline 26/(08 18 Ministro da R. Agrárial lanca projeto $\mathrm{p} /$ compra de icrats no PR & $0: 15$ \\
\hline 27/08 17 Conflito entre sem terrat c donos de fazenda & $0: 49$ \\
\hline 28/08 10 Militantes do MST: alguns utilizam mal a lema & $2:(1) 8$ \\
\hline 2) TJ-Brasil & \\
\hline 28707 12 MST: politica agressiva dos lideres ao sug & $2: 37$ \\
\hline T6/08 2 Pontal: Icnsão c almeaça de invasão pelo MST & $T: 15$ \\
\hline 18/08 I Pontal: líderes do MST dizem que invasões cstão só começando & $2: 49$ \\
\hline 20/08 14 MST quer liberação de verbas e amcaça invadir agênciass & 1:34 \\
\hline 27/08 I Sem icrras invadem lazenda c ameaçam arrendatário da terra & $1: 03$ \\
\hline 30/08 16 Presidente visita acampamento de sem-tera perto de sua fat\%e & $1: 36$ \\
\hline 30/08 17 Entrevisla com Scligman: processo de Rainhal c & $2: 50$ \\
\hline
\end{tabular}

Em linhas gerais, é possível caracterizar o enquadramento dado ao MST nos telejornais com ênfase em três principais linhas 
interpretativas: a escalada do conflito, com seu enquadramento dramático; a ilegalidade e imoralidade da violência política; e, finalmente, a irracionalidade e ineficácia econômica do MST.

\section{1) Escalada do conflito:}

Ambos os telejornais abrem espaço para o MST em suas coberturas em função do acirramento dos confrontos armados envolvendo, de um lado, o movimento, e, de outro, ou os fazendeiros proprietários de terras invadidas (ou a invadir), ou a polícia militar, enquanto mediador público do conflito (muitas vezes, contudo, agindo contra o MST e em defesa do direito à propriedade garantido pelo Estado). Sem dúvida que, para além de qualquer motivação ou constrangimento político ou ideológico específico, a abertura dos mídia para a cobertura de conflitos armados tende a se justificar pela atribuição usual (ou consensual) ao público de interesse por esse tipo de conteúdo. Trata-se, afinal, de um enquadramento costumeiro e utilizado na cobertura de qualquer conflito, independentemente de suas razões políticas.

Não surpreende, portanto, que nas três ocasiões em que as coberturas dos dois telejornais se ocuparam, ao mesmo tempo, do MST nos dias 16,20 e 27 de agosto - isto se deveu ao aumento da tensão provocado pelas invasões (ou ameaças de), fazendo também com que a cobertura nestes dias, em ambos os veículos, enfatizassem os próprios elementos narrativos relativos, antes de mais nada, ao conflito (ou ao risco de conflito), pura e simplesmente.

Na primeira matéria de nossa amostra, que vai ao ar no dia 28 de julho, uma segunda-feira, no $\mathrm{TJ}$, já fica claro o tipo de enquadramento dado pelo jornal ao assunto. Hermano Henning introduz a matéria: "Líder do Movimento dos Sem-Terra volta a pregar a invasão nas cidades. Diz que o povo precisa se rebelar contra o governo e manda um recado para o juiz que o denunciou por incitar as invasões urbanas. Heraldo Pereira." A fala do âncora, repleta de termos indicadores de conflito e agressividade - como "pregar a invasão", "rebelar contra o governo" e "incitar as invasões urbanas" - refere-se, na verdade, aos poucos segundos, já no final da matéria, em que João Pedro Stédile repete o argumento que já havia sido reproduzido exaustivamente nos meios de comunicação: "A solução pros sem-teto é continuar se organizando e ocupando os terrenos baldios que só servem para especulação imobiliária. E aos famintos, se organizem e se manifestem na frente dos supermercados, das igrejas, do palácios e dos fóruns". Colocando este apelo como "um recado para o juiz que o denunciou", o TJ reforça o enquadramento dramático e polarizado que dá ao conflito. 
A matéria mostra imagens do Encontro Nacional dos Educadores da Reforma Agrária. O motivo da assembléia, no entanto, só é explicitado pelo repórter em torno do meio da matéria. Até então, as imagens mostram Rainha e Stédile, com outros integrantes da mesa, cantando com o punho levantado - a parte da letra que se ouve diz: "Nossa pátria livre e forte..." Os participantes do encontro, muitos com camisetas e bonés do MST, também cantam e levantam os punhos. As palavras de ordem gritadas, bem como a fala de Rainha, cuja imagem aparece ao microfone, ficam em segundo plano. A narração fica por conta do repórter, que, em off, fala de "postura mais agressiva em relação ao governo Fernando Henrique Cardoso", e continua: "Com um discurso cada vez mais político e de oposição, os dois chegam a falar da volta do comunismo, e se referem a grupos internos do MST, como Brigada Nacional, responsável pela organização de pelotões populares [para fazer] (...), na Semana da Pátria, manifestações contra o governo e (...) o chamado grito dos excluídos". O TJ fala, ainda, do "plano dos líderes sem-terra". A recorrência de termos militares reforça a dramaticidade do conflito.

A palavra final, contudo, é a do governo, que desqualifica as ambições políticas do MST. O repórter Heraldo Pereira, falando de Brasília e tendo ao fundo o Palácio do Planalto, resume a "reação do governo": "o ministro da Reforma Agrária, Raul Jungmann, está em viagem para o exterior. E o presidente do Incra, Milton Seligman, manda dizer que não vai bater boca com o pessoal do MST. O que eles buscam é não criar polêmica com os líderes do Movimentos dos Sem-Terra. Na avaliação do governo, as lideranças do MST buscam ocupar um espaço político deixado por tradicionais lideranças dos partidos de oposição a Fernando Henrique Cardoso. Por isso a ordem do Palácio do Planalto é, neste momento, não dar aos líderes do MST a importância política que de fato eles não têm".

Embora o TJ enfatize, portanto, a superioridade do governo no confronto, em diversos momentos notamos referências à organização política e a decisões estratégicas do MST, o que, dentro do enquadramento dramático identificado, ajuda a alçá-lo à condição de um adversário de peso para governo e fazendeiros. No dia 16, assim, depois de 19 dias sem tocar no tema, o TJ traz o conflito agrário para o primeiro bloco do jornal, focalizando, justamente, a expectativa em torno da realização de uma assembléia do Movimento: "Clima de tensão no Pontal do Paranapanema (...) O Movimento dos Sem-Terra ameaça com novas invasões a partir de amanhã, e os fazendeiros prometem reagir com a contratação de seguranças armados. A repórter Simone Queiroz está no Pontal, e dá as informações 
por telefone". A repórter, em off sobre sua foto, começa: "Nós estamos aqui no acampamento dos sem-terra em Taquaruçu, município de Pontal do Paranapanema. É aqui que vai acontecer amanhã, às nove horas, a principal assembléia do MST, que deverá decidir as próximas ocupações aqui no Pontal. (...) Segundo os sem-terra, durante todo o dia, seguranças das fazendas estiveram nas proximidades dos acampamentos. Esse aonde nós estamos agora é ao lado da São Domingos, considerada improdutiva. São quase cinco mil alqueires, onde é possível assentar 700 famílias. Os fazendeiros membros da UDR pediram reforço na segurança à Polícia Militar. Esse portanto o motivo da tensão aqui no Pontal."

O TJ, mais uma vez, concede ao MST uma voz mais política e articulada do que o JN, embora a fragmentação distintiva do meio torne o acompanhamento mais aprofundado da notícia quase impossível. Assim, noticia-se para o dia seguinte "a principal assembléia do MST", sem que se tenha falado disto nos momentos anteriores, e sem que a matéria seguinte, dois dias depois, faça referência a qualquer assembléia como sendo o fórum político onde se decidiram as novas invasões. No dia 18 , assim, o enquadramento destaca as ameaças e rebeldia dos sem-terra, a polarização do conflito e o crescente armamento e violência dos adversários, contrastando com a atividade da polícia visando manter a paz e a ordem. A repórter, em off, relata os eventos, começando por dizer que "os sem-terra romperam a trégua de seis meses", invadindo uma fazenda, derrubando as cercas e colocando fogo no pasto. O foco central da matéria, no entanto, são os bloqueios feitos pela Polícia Militar para "impedir a entrada de pessoas armadas na região de possíveis conflitos entre a UDR e os sem-terra". A repórter, depois, acompanha a "entrada de dois integrantes do MST numa assembléia da União Democrática Ruralista, na Fazenda São Domingos", e o conseqüente bate-boca. O noticiário trata todas as situações com linguagem quase militar, procurando sempre caracterizar o drama do conflito.

A ênfase nos aspectos dramáticos do conflito também está presente na cobertura do JN, embora, como veremos adiante, não seja a mais importante. No dia 20, por exemplo, Lílian Witte Fibe introduz a notícia sobre os sem-terra, com a vinheta do MST ao fundo. "Semterra invadem fazendas produtivas no Paraná. E os fazendeiros comtratam seguranças armados para impedir novas ocupações". Em seguida, o repórter comtinua, sobre imagens noturnas de fogo: "O fogo é um sinal da invasão. A pastagem da fazenda é queimada pelos sem-terra, e os tratores do MST dominam a área. Na hora de tomar o pedaço de terra, os invasores ignoram cercas e limites". Depois das 
imagens de tratores com bandeiras do MST, um grupo de sem-terra aparece no vídeo. O cenário ainda é noturno. Um deles, não identificado, diz: "Porque é o seguinte: a reforma agrária vai sair. Na lei ou na marra ela sai". Embora a frase seja audivel, o sentido de confronto é reforçado pelo recurso a uma legenda: "A reforma agrária vai sair, na lei ou na "marra' ela sai". (...)

$O$ aparecimento do poder instituído, como sempre, traz apelos à ordem e à paz. A funcionária do governo, identificada como "Maria de Oliveira, superintendente do Incra /PR", tem fala burocrática e conciliatória: "A preocupação é de não ter a necessidade da última esfera do judiciário impor uma condição à secretaria de segurança. através do governo do Estado, a desocupação forçada. Nós não queremos briga no Estado".

$O$ enquadramento dramatiza e polariza claramente o conflito. $O$ repórter continua, mostrando um grupo de homens vestidos como ninjas - roupas e capuzes pretos - fortemente armados e equipados. "Do lado de dentro das cercas, fazendeiros exibem o poder de fogo. Seguranças particulares contratados para impedir novas invasōes. Homens que escondem o rosto, armados com escopetas calibre 12. semi-automáticas, e equipados com binóculos especiais para enxergar à noite, e rádios para se comunicarem com outras propriedades (...). Pelo menos seis fazendas aqui da região de Querência do Norte já contrataram grupos armados como este, e têm ordens para reprimir qualquer tentativa de invasão dos sem-terra a bala". O tom violento da notícia é confirmado por um dos "ninjas": "A ordem aqui é pra atirar e não deixar entrar, sem possível até matar". O conflito cresce de proporções na medida do progressivo armamento dos adversários, e a tônica da matéria é a violência iminente do confronto.

No dia 27 , o tema ganha pela segunda vez a primeira matéria do TJ. "Confusão e tiroteio numa fazenda ocupada por sem-terra $\mathrm{em}$ Londrina, no Paraná. Os manifestantes atearam fogo no carro do arrendatário da área e anunciaram: estão dispostos a tudo para não sair da região ocupada", introduz Hermano Henning. E continua, em off. sobre longas tomadas de um carro queimado, totalmente destruído, ainda em chamas: "O arrendatário foi checar uma denúncia de que os sem-terra estariam destruindo uma área de plantação. Homero Palma afirma que foi recebido a balas e fugiu. Depois disso, os manifestantes atearam fogo na Brasília dele. Os sem-terra admitem ter queimado o carro, mas alegam que os tiros não saíram do acampamento". Um sem-terra, filmado em contra-luz para não ser reconhecido, prática comum no telejornalismo policial, dá sua versão: "Ele chegou atirando, com mais de 15 pistoleiros junto". 
O fazendeiro, ao contrário dos sem-terra, é insistentemente nomeado pelo âncora. Sua versão é reforçada por imagens do documento de reintegração da área. E tem mais espaço, bem como enquadramento dramático, ao dar sua versão da história: "Na porta da minha casa, na rua, meus filhos (as imagens mostram a mulher, e três adolescentes) não podem mais sair de casa, fica aquela tensão, eu com o tratorista que estavam trabalhando na roça dando proteção na porta da minha casa... Mas desarmado, eles tavam". Para o depoimento seguinte, o noticiário escolhe outro sem-terra do acampamento em conflito, vestido de maneira exótica - lenço e chapéu na cabeça, longa barba negra e um pano vermelho amarrado nos ombros: "Se eles vier pra matar nós, fazer que nem fizeram ontem, que eles vier, nós vamos meter-lhe a foice e o facão pra matar mesmo".

$\mathrm{O}$ mesmo evento é apresentado pelo JN de forma semelhante. "Mais um conflito entre agricultores sem-terra e seguranças de uma fazenda invadida no Paraná. 42 famílias ocuparam a área, em Alvorada do Sul, no mês passado. Estavam destruindo uma lavoura de aveia para plantar mandioca. $\mathrm{O}$ arrendatário da fazenda apareceu, acompanhado por um grupo de dez homens. Houve troca de tiros, mas ninguém ficou ferido". Em off, sobre as imagens da Brasília em chamas, a apresentadora continua: "Depois do tiroteio, os sem-terra botaram fogo no carro do arrendatário, Homero Palma. O arrendatário e os sem-terras trocam acusações sobre quem começou a confusão. A Justiça já determinou a reintegração de posse da fazenda, mas a ordem de retirar os sem-terra ainda não foi cumprida, e eles prometem resistir". Curiosamente, o sem-terra escolhido para falar ao microfone é o mesmo da matéria do TJ, e seu depoimento é igualmente agressivo. Ele mostra a foice, e, imitando o gesto da repórter, que passa o dedo na lâmina, diz: "A minha eu amolei bem, porque se acaso eles chegar, que daí eu vou ter que cortar muito pescoço, porque não vai ficar assim".

Podemos perceber, na freqüência com que ambos. os telejornais recorrem à versão oficial das autoridades constituídas para concluir as matérias sobre os conflitos de terra, a presença do segundo enquadramento significativo na cobertura de ambos os telejornais: a desqualificação moral da violência empregada pelos sem-terra.

\section{2) Imoralidade/ilegitimidade da violência política:}

Um segundo enquadramento recorrente poderia ser caracterizado pelos mecanismos formais e conteudísticos de deslegitimação da intervenção política do MST pelo uso da violência e desrespeito ao direito de propriedade. Embora seja evidente que este tipo de enfoque 
tende a se viabilizar em conjunto com a simples cobertura da escalada das tensões - já caracterizado anteriormente - ele possui, contudo, a sua própria especificidade e autonomia em relação ao item anterior. De modo que, independentemente do aumento ou diminuição da tensão e da efetivação ou não de confronto, a desqualificação narrativa do uso de medidas radicais por parte do MST pode se dar, através, por exemplo, da abertura para o discurso das autoridades, da exibição de propostas alternativas (e pacíficas) de resolução do problema fundiário, etc.

$\mathrm{O}$ conjunto de duas matérias veiculadas em sequência no dia 5 de agosto, uma terça-feira, no JN, é ilustrativo do enquadramento típico dado pelo telejornal ao tema. A primeira matéria, com 1'02", apresenta os sem-terra como violentos desperdiçadores do patrimônio alheio. Lílian Witte Fibe introduz a matéria, com ao fundo, à esquerda, a vinheta. "O governo do Mato Grosso do Sul pediu ajuda à União para resolver o impasse com o sem-terra que ocuparam uma fazenda no município de Itaquirai (...). Hoje os invasores mataram mais de 40 cabeças de gado, e prometem continuar abatendo as vacas, se o governo não mandar cestas básicas para o acampamento". Nas imagens que se seguem, predominam as da pilha de carne, e a de um sem-terra que, provocador, a espingarda na mão esquerda, roda no ar, com a direita, olhando para a câmara, a ponta do rabo de uma vaca. A narração, em off, enfatiza as "carabinas e cartucheiras" usadas na matança, o prejuízo para o dono da fazenda, "considerada produtiva pelo Incra", e a ilegalidade de toda a operação: "O fazendeiro ganhou na justiça a reintegração da área, mas os sem-terra se recusam a sair".

As autoridades governamentais são explicitamente apresentadas como restabelecedoras da ordem ameaçada pelos sem-terra, e a violência destes parece injusta e gratuita. O enquadramento moralista já começa a ser desenhado, com os sem-terra ocupando o pólo negativo da relação, e o governo o positivo.

A matéria seguinte, na mesma edição, tem 1'53" e, embora centrada na atuação de um governo municipal, funciona como reforço ao argumento implícito, contido na primeira, de que a violência usada pelo MST, além de questionável moralmente, é inferior em termos de resultado aos esforços das autoridades constituídas. Outro apresentador introduz a matéria com as seguintes palavras: "De um lado a violência, do outro, uma solução: uma prefeitura do Paraná combate o crescimento das favelas promovendo a volta do agricultor para o campo. Eles recebem semente, adubo e até um porquinho para voltar a cultivar a terra". Humanista, a matéria fala da "frustra- 
ção" de quem trocou o campo pela cidade e conheceu "o lado hostil da vida urbana". Toda a matéria é feita a partir do ponto de vista da prefeitura, embora haja vários depoimentos, em geral com não mais de uma frase, de agricultores desiludidos.

"Para voltar ao sítio que abandonou, o agricultor Mário da Cruz está recebendo o chamado kit rural, que inclui a mudança, uma cesta básica, sementes de verduras e legumes, uma leitoa e pintinhos para começar uma criação", narra, em off, a repórter, enquanto as imagens mostram a assistente social da prefeitura (única funcionária do governo não identificada nas matérias estudadas) entregando os sacos e animais. O tratamento conferido aos agricultores é paternalista. A assistente social fala dos cuidados para com os pintinhos: "Água fresca, e pra dormir eles são que nem criança nos primeiros dias: você bota na caixinha, se tiver uma roupinha velha, um jornal, põe junto. Eles dormem, eles aprendem sozinhos". Segundo o repórter, os agricultores recebem também assistência técnica. A assistente: "Nós acompanharemos essas famílias todo o tempo, até que a gente veja que eles estão em condições de se manter de pé sozinhos". Coisa que, aparentemente, sem a ajuda da prefeitura, os humildes habitantes de Castro, no Paraná (um dos principais cenários do confronto entre sem-terra, fazendeiros e governo), não saberiam fazer.

O depoimento seguinte é de outro agricultor, já beneficiado há algum tempo pelo projeto da prefeitura. Mostra de vários ângulos a casa e o automóvel que conseguiu comprar, o gado que está criando "com a ajuda da família", a leitoa e os franguinhos que ganhou no kit rural, já crescidos. Os personagens da notícia são chamados agricultores - qualificação nunca reservada para os sem-terra, nem assentados - e a matéria abusa de diminutivos, do tom emotivo e paternalista. Esta notícia, ao contrário da anterior, não se centra em algum evento do momento. Trata-se de uma produção da própria emissora, pois o projeto da prefeitura de Castro, como vemos, já está em andamento há algum tempo. Sua veiculação, imediatamente após as fortes imagens do "massacre das vacas", constrói dialeticamente o enquadramento proposto, moralista e oficialista.

Mais uma vez estamos aqui diante de um tipo de enquadramento que é objeto das práticas de ambos os telejornais. Chama atenção, ainda, que, embora também esteja implícito no enquadramento a crítica ao uso da violência também pelos fazendeiros, esta é geralmente apresentada como reativa, especialmente no JN. Assim, em matéria do dia 13 de agosto que mostra os fazendeiros se armando para o conflito, com funcionários cavando trincheiras e verificando cercas, a sonora escolhida para ir ao ar é de um jovem fazendeiro de bigodes, recosta- 
do em sua pick-up último modelo, que diz: "Eu acho que a pessoa tem que se defender. Se vierem com estilingue, com estilingue; se vier com tapa, com tapa; se vier com arma, com arma". Três dias depois, em matéria muito parecida, o JN retoma o tema, informando que: "Os fazendeiros fazem trincheiras para proteger uma fazenda ameaçada de invasão no interior de São Paulo. Nesta mesma fazenda, oito sem-terra foram feridos a bala no começo do ano". O repórter: "Os fazendeiros sobrevoaram hoje acampamentos dos sem-terra no Pontal do Paranapanema, e mandaram que os funcionários fizessem uma proteção de terra na divisa com um dos acampamentos..."

Pela primeira vez no período, o JN abre o microfone para um representante dos sem-terra, identificado como "Antônio Oliveira, coordenador do acampamento". "Nós tamos vendo o que vai decidir na nossa reunião de domingo, na nossa Assembléia, creio que sim, nós vamos ocupar sim a fazenda, porque já é nossa, né?" Esta é a única referência feita pelo JN à Assembléia do MST, sem maiores explicações. Imediatamente depois, o mesmo fazendeiro, com boné da UDR, identificado como "Guilherme Prata, vice-presidente da UDR": "Eu que moro na minha fazenda, que vivo daquilo, pago a escola das minhas crianças com aquilo lá, eu defendo de unhas e dentes e da maneira que eu achar necessário e da maneira que eu for agredido". A violência dos fazendeiros, mais uma vez, aparece como reativa: "da maneira como eu for agredido".

Para além do apelo sensacionalista do conflito em si, e da desqualificação da violência como instrumento de pressão política, outro enquadramento é extremamente importante na construção das narrativas sobre o MST, especialmente no JN.

\section{3) Irracionalidade e ineficácia econômica do MST:}

Este terceiro tipo de enfoque será aquele que nos possibilitará uma mais clara diferenciação entre os dois telejornais da amostra. Se caracteriza pela ênfase na análise não do conflito propriamente dito mas sim da eventual (e provável) inutilidade do esforço e dos custos implicados pela ação política violenta do MST, dada a suposta (e afirmada) incapacidade de seus membros de utilizar a terra de modo produtivo. Ou seja: além de ilegítima - porque violenta e ilegal - a ação do MST seria irracional porque não garantiria um uso adequado da terra por ele ocupada. Para que tal produtividade fosse possível seria necessário ou deixar a terra produtiva nas mãos de quem, legalmente, já a possui, ou redistribui-la, sim, para trabalhadores sem-terra, mas através de uma política eficiente e consequiente de reforma agrária, a qual, evidentemente, só pode ser levada a cabo pelo governo, com seu apoio técnico 
e financeiro. O mesmo governo que o MST insiste em desafiar.

Muito significativamente, este é um tipo de enfoque utilizado somente pelo Jornal Nacional. Embora o TJ também, geralmente, conceda aos porta-vozes do governo a última palavra, a prática de alternar matérias sobre a violência e ineficiência do MST com matérias sobre políticas agrárias bem-sucedidas do governo é exclusiva do JN, como se vê no Quadro 2.

A última matéria do JN no período é uma síntese deste enquadramento. No dia 28 , vai ao ar uma reportagem que, embora não se refira a nenhum evento em particular - trata-se de uma produção da própria emissora - ganha, no bloco anterior, uma das três chamadas do JN para o tema. Lílian: "Em instantȩs: as contradições na luta pela Reforma Agrária". William Bonner completa: "Assentados que produzem; assentados que só se divertem"; a chamada mostra imagens de um homem plantando e outros jogando bilhar. Imediatamente após o intervalo comercial, Lílian introduz a matéria, com ao fundo a vinheta do MST: "Plantação que virou campo de futebol; áreas que foram entregues aos sem-terra tomadas pelo mato. Muitos militantes do MST aproveitam bem a terra que recebem, outros nem tanto". A reportagem inicia com tomadas aéreas de um acampamento sem-terra. O repórter, em off: "Em um mês, três fazendas invadidas. Mil famílias de sem-terra acampadas. [Tomada aérea mais próxima do acampamento.] Na mira dos integrantes do MST na região de Nova Cantú estão grandes fazendas, [Tomada aérea de grandes extensões verdes de terra cultivada] onde se cria gado [Tomada aérea de rebanho correndo em grande pasto verde] e se planta soja, milho e aveia". Segue a imagem de um homem jovem não identificado, de barba e camiseta: "Nossa meta é continuar invadindo, por causa do trabalho. Se nós não invadir, nós vamos trabalhar aonde?"

O repórter continua no céu. Enquanto fala, vê-se mais uma vez um acampamento, primeiro de cima, depois por entre árvores. "Na mesma região onde as invasões não param, áreas já entregues para assentamentos definitivos de sem-terra são exemplos de uma reforma agrária que não deu certo. [Imagem do repórter, que fala de dentro de um helicóptero.] Aqui de cima se vê melhor esse contraste entre as grandes fazendas e os assentamentos do Incra na região. [A câmara desloca a imagem para fora do helicóptero.] Essa área é uma fazenda de criação de gado que os sem-terra tentaram ocupar. Do outro lado da estrada, está um assentamento do Incra feito nove anos atrás. Metade da área está sem uso".

Após a abertura, dramática e incontestável, devido às eloqüentes imagens aéreas comparativas, aparecem imagens de mato alto entre construções, das quais só se vê o teto; mais mato, para além de uma 
cerca; e, finalmente, uma varanda de bar, só com telhado, uma mesa de bilhar onde alguns homens sentados e um de pé bebem cerveja. "O mato toma conta do assentamento. Em vez de cuidar da terra que receberam de graça, muitos assentados passam o tempo bebendo e jogando. Quem não trabalha na terra que tanto queria tenta se justificar como pode. Fala um homem de boné, em plano americano, identificado como "José Cavalírio, assentado": "Tá faltando bastante é apoio técnico pra gente". Outro, identificado como "Valmir Araújo, assentado": "Falta de dinheiro, falta de ajuda do governo..." O repórter: "Arlindo Campos abandonou a lavoura mas continua no assentamento. No lugar da plantação, um campo de futebol. E um bar. O ex-sem-terra virou comerciante". Arlindo se explica, filmado sem camisa, no balcão do bar-mercearia: "O investimento da agricultura, o insumos agrícolas é muito caro, então eu tenho que jogar todas as moedas que eu tenho pra se sair". O repórter, em off, esclarece que "a atitude não agrada aos vizinhos, invasores que ainda são sem-terra". As imagens mostram três sem-terra conversando numa estrada de terra; uma fila de sem-terra encostados numa cerca; um menino correndo por um pasto. Os sem-terra depõem. "Hamilton Pereira, sem-terra": "Diz que o dinheiro veio, pra turma trabalhar, mas tem uns caras que não tem aquela esperteza de querer vencer, né, quer é ficar naquela ali. "a Celestino, sem-terra", este um senhor idoso, de chapéu: "Aqueles que não têm, passa pra outro que tem vontade de trabalhar, né?"

A ênfase na gratuidade da terra recebida contrasta com o mau uso que dela fazem os assentados retratados. No final da matéria, um único contra-exemplo, que não desfaz a impressão negativa oferecida ao longo da reportagem. Um assentado bem-sucedido, filmado em frente a sua casa de tijolos e a seu fusca azul, trabalhando no campo e cuidando dos bezerros. O repórter narra a história: "Durvílio Capitani é um exemplo de quem soube aproveitar a terra que ganhou. Com a ajuda da família, cria gado, e produz mandioca e aveia. Já conseguiu construir uma casa e comprar um carro". A frase de Durvílio selecionada para ir ao ar: "Ah, tendo a terra, e vontade, só se vai pra frente".

Vejamos então o quadro abaixo com a proporção de tempo utilizado por cada telejornal na utilização dos diferentes enfoques descritos:

\begin{tabular}{|llc|}
\hline \multicolumn{3}{c|}{ Quadro 3. Temas Principais } \\
Tema & JN & TJ \\
1) Escalada do conflito & $2,16 " 18,98 \%$ & $4,55^{\prime \prime} 39,33 \%$ \\
\hline 2) Imoralidade/ ilegitimidade de violência & $4,199^{\prime \prime} 36,82 \%$ & $7,02 " ' 60,67 \%$ \\
\hline 3) Irracionalidade e incficácia econômica & $5,033^{\prime \prime} 44,29 \%$ \\
\hline
\end{tabular}


A partir destes dados podemos extrair as seguintes conclusões relativas ao tratamento dado ao MST pela cobertura telejornalística do JN e do TJ ao longo do mês de agosto de 1997:

1) Embora ambos os jornais dediquem considerável espaço para a cobertura do MST simplesmente como partícipe e motivador de conflitos armados - o que já seria suficiente para despertar a atenção de uma mídia competitiva - é significativo que enquanto no TJ esse tipo de enquadramento mercadológico básico seria responsável, grosso modo, pelo enfoque principal dado a cerca de $40 \%$ do espaço noticioso relativo ao assunto, no $\mathrm{JN}$ esse mesmo tipo de enquadramento teria um peso proporcionalmente muito inferior (menos da metade).

2) Por outro lado, quando os enquadramentos dos dois telejornais assumem um tom mais crítico e os veículos exercem os seus auto-assumidos papéis de formadores de opinião - o que se daria, portanto, em cerca de $60 \%$ da cobertura do TJ e em cerca de $80 \%$ da do JN! - mesmo assim as diferenças de enfoque são gritantes: enquanto o $\mathrm{TJ}$ se resume a deslegitimar a violência política do MST - por sua violência - o JN prefere diversificar a sua crítica, incorporando não apenas esse tipo de juízo especificamente moral, jurídico e político, mas acrescentando a ele, também, um específico conteúdo técnico e econômico.

Elaboremos, a título de conclusão, algumas hipóteses para a compreensão dessas diferenças e seus significados.

\section{A título de conclusão}

O objetivo deste artigo foi identificar padrões de leitura propostos para o assunto em questão, visíveis nas narrativas, na caracterização dos personagens, na definição dos termos do conflito, em coisas simples como a adjetivação dos atores políticos e eventos a elementos visuais sutis, provavelmente imperceptíveis para a maioria dos espectadores, submetidos à avalanche diária de informações para as quais normalmente tem pouco interesse. Este enquadramento, insignificante no singular, ganha importância na recorrência, constituindose em um padrão de cobertura a partir do qual pode-se explicar em termos simplificados um fenômeno político complexo como o MST e a luta pela terra. Uma explicação estrutural que pode ter contrapartida, na opinião dos cidadãos, em outras fontes de informação política, mas cuja influência potencial não deve ser desconsiderada, num país em que a maior parte da população depende exatamente da televisão - mais especificamente, destes mesmos canais abertos que agora se "tabloidizam" - para construir os esque- 
mas a partir dos quais organizam o "mundo lá fora", para além da experiência concreta.

Para uma análise que se permitisse conclusões efetivas sobre as relações entre o jornalismo televisivo e o Movimento dos Sem-Terra, seria necessário, sem dúvida, considerar todo o jogo de relações interativas entre os participantes: o próprio movimento, seus adversários - de um lado, os fazendeiros; do outro, o governo -, os meio de comunicação, com suas especificidades, e as audiências para quem estes noticiários são feitos, bem como a visão dos adversários sobre a cobertura recebida, seus esforços intencionais em relação à publicidade e, não menos importante, as repercussões da cobertura junto aos cidadãos telespectadores, ponderada, é claro, pelas outras variáveis modificadoras - ou mantenedoras - da opinião pública.

Este ensaio, bem menos ambicioso, pretendeu apenas perceber regularidades nas notícias veiculadas sobre o tema nos dois principais telejornais do país, que à época somavam juntos cerca de $50 \%$ da audiência. Sem entrar na complexa discussão acerca dos eventuais efeitos de tais matérias na opinião dos indivíduos a respeito de um movimento social e político, elas são sem dúvida fonte importante a partir das quais pessoas na maior parte dos casos afastadas da cena dos eventos podem pensar o mundo político.

Filtrados pelo prisma enquadrante dos telejornais, temos portanto uma série de definições, simbólicas e retóricas, a respeito da participação dos atores políticos no conflito. A própria linguagem específica do jornalismo televisivo tenderia a polarizar e dramatizar os eventos, através de mecanismos como certas expressões dos apresentadores, que remetem a fatos que, imagina-se, sejam conhecidos dos espectadores. Nem sempre, contudo, estes fatos estiveram realmente presentes nos noticiários anteriores do mesmo jornal; presume-se, portanto, um conhecimento do leitor, em relação aos fatos, maior do que o fornecido na própria matéria. O tom das reportagens usava de recursos semelhantes ao dos autores que, não querendo ofender o leitor explicitando sua ignorância, começam uma explicação afirmando: "Como todos sabem(os)..."

Isso permite à notícia usar enquadramentos com diferentes graus de explicitação, sem contudo fugir aos principais padrões de cobertura: ambos os jornais apostavam no potencial sensacional do tema, usando recorrentemente enquadramentos que reforçavam a violência e tensão inerentes ao conflito.

Enquanto, porém, o TJ reforçava os elementos de perigo, iminência de combate, confronto e polarização, num exemplo claro do que chamamos de enquadramento dramático, e ao julgar o MST 
assumia um tom crítico e moralista apenas em relação ao uso que este fazia da violência política, o JN assumia, além disso, um enquadramento racionalista em relação ao movimento, reproduzindo a postura oficial de deslegitimar politicamente o MST, negando a ele capacidade técnica e, portanto, autonomia, e retratando os sem-terra como violentos, irresponsáveis e pouco dignos de confiança.

O oficialismo, na verdade, estava presente nas notícias de ambos os jornais. Acreditamos, porém, que a presença unilateral de um argumento racionalista - com base não apenas na denúncia moral ou na defesa da legalidade - no discurso do Jornal Nacional, chama a

108 atenção para o distinto caráter civilizador que este veículo se atribui em nossa sociedade, resultante e motor do autêntico processo de institucionalização deste telejornal em função de sua longevidade e de seu status até hoje intocado de campeão de audiência (além de principal noticiário da emissora líder). Num certo sentido, se poderia dizer que o JN fala para um país que ainda precisa ser construído. $\mathrm{E}$ onde, evidentemente, não há lugar para as práticas e as capacidades de um movimento como o MST.

Por outro lado, tanto a ênfase posta pelo TJ na escalada dos conflitos, quanto a moralização do enfoque dado por ele ao MST parecem creditáveis à inserção mercadológica e altamente competitiva do telejornal e sua emissora junto a segmentos populares e de baixa renda. É como se, antes de mais nada, o TJ se dedicasse a cativar atenção do seu público com a crônica do nosso "estado de natureza", de nosso cotidiano de violência, injustiça e impunidade, e do qual o drama do MST não seria nada além de uma nova faceta (politicamente qualificada). Violência cujo combate, por sua vez, não passa porém pela política, se limitando à pura e simples prédica moralista.

Essas e outras hipóteses deverão ser melhor exploradas no seguimento da análise aqui iniciada.

\section{Notas}

1 Este artigo foi escrito com base em dados do acervo do Laboratório de Pesquisa em Comunicação Política e Opinião Pública, do IUPERJ. A planilha para coleta de dados foi elaborada no âmbito da pesquisa "Brasil em transição: um balanço do final do século", aprovada pelo Pronex e sediada no CPDOC da Fundação Getúlio Vargas, no Rio de Janeiro.

2 Goffman, Erwin. Frame analysis. New York, Harper and Row, 1974, p. 10-11. Citado por Cohen, Akiba e Wolfensted, Gadi. Framing the Intifada: people and media. Norwood, Ablex, 
1993, p. xiv

3 Fiske e Kinder, "Involvement, expertise and schema use: evidence from political cognition", 1981, p. 173, citados por Entman. Robert. Democracy without citizens. Nova York, Oxford University Press, 1989.

4 Gitlin, Todd. The Whole World is Watching: mass media and the making and ummaking of the new left. University of California Press, Berkeley/Los Angeles, 1980, p. 7.

5 Bird, S. Elizabeth \& Dardenne, Robert W. "Myth, chronicle, and story: exploring the narratives qualities of news" in: James W. Carey (ed.), Media, myths and narratives, Newbury Park \& London, Sage 1988.

6 Ver Neuman, W. Russell, Just, Marion R. e Crigler. Ann N. Common Knowledge: news and the construction of political meaning. University of Chicago Press, 1992.

7 Waisbord, Silvio. "Contando histórias da corrupção: narrativa de telenovela e moralidade populista no Caso Collorgate". Commnicação e política, v. Ill, no. 2 (nova série), 1996; Fausto Neto, Antônio. O impeachment da televisão. Rio de Janeiro. Diadorim, 1995.

\section{Biblografia}

CAREY, James W. (ed.) Media, myths and narratives. Newbury Park \& London, Sage 1988

COHEN, Akiba \& Wolfensted. Gadi - Framing the Intifada: people and media. Norwood, Ablex, 1993, p. xiv

ENTMAN, Robert. Democracy without citizens. Nova York, Oxford University Press, 1989.

GITLIN, Todd. The Whole World is Watching: mass media and the making and unmaking of the new left. University of California Press, Berkeley/Los Angeles, 1980.

NEUMAN, W. Russell, Just, Marion R. e Crigler, Ann N. Common Knowledge: news and the construction of political meaning. University of Chicago Press, 1992.

WAISBORD, Silvio. "Contando histórias da corrupção: narrativa de telenovela e moralidade populista no Caso Collorgate". Comumica- 
ção e política, v. III, no. 2 (nova série), 1996; Fausto Neto, Antônio. O impeachment da televisão. Rio de Janeiro, Diadorim, 1995.

Palavras-chave:

1. telejornalismo político;

2. MST;

3. análise de enquadramentos;

4. comunicação política;

5. telejornais. 